\title{
Mosquitoes (Insecta: Diptera: Culicidae) of the Florida Keys, Florida, United States of America
}

\author{
Lawrence J. Hribar ${ }^{1 *}$, Andrea L. Leal ${ }^{2}$, David J. DeMay ${ }^{1}$ and Adriane N. Tambasco ${ }^{3}$ \\ 1 Florida Keys Mosquito Control District, 503 107th Street, Marathon, FL 33050, USA. \\ 2 Florida Keys Mosquito Control District, 5224 College Road, Key West, FL 33040, USA. \\ 3 Florida Keys Mosquito Control District, 100701 Overseas Highway, Key Largo, FL 33037, USA. \\ * Corresponding author. Email: Ihribar@keysmosquito.org
}

\begin{abstract}
A list of the Culicidae collected in the Florida Keys is presented. Mosquito records were obtained from the scientific literature and from collections made by mosquito control personnel. Forty-eight species or species groups are known from the Florida Keys.
\end{abstract}

\section{INTRODUCTION}

The Florida Keys comprise an archipelago that surrounds the southern tip of the state of Florida (Figure 1). Although the word "key" is used for many small islands near the Florida coast, the Florida Keys proper are those islands extending from Soldier Key in the northeast to Key West in the southwest. There is a natural division in the island chain, the Upper Keys, those from Soldier Key to Bahia Honda Key; and the Lower Keys, those from Big Pine Key to Key West. The division is due to the underlying rock: the Upper Keys are composed of Key Largo Limestone and the Lower Keys of Miami oölitic limestone (Hoffmeister and Multer 1968). The Upper and Lower Keys differ in terms of vegetation, rainfall, and permeability of bedrock (Stern and Brizicky 1957; Snyder et al. 1990; Corbett et al. 1999). The highest point in the Florida Keys is about 5.5 meters above sea level; most of the islands lie below 2 meters above sea level (Ross et al. 1992).

Mosquitoes (Insecta: Diptera: Culicidae) are perhaps the most important haematophagous insects impacting human and animal health. They serve as vectors of numerous disease organisms, including bacteria, protozoa, and helminths. Mosquitoes also serve as food items for other animals.

\section{MATERIALS AND Methods}

Mosquito records were located via review of relevant literature and from unpublished collection records of the Florida Keys Mosquito Control District. Collections of mosquitoes were made by Florida Keys Mosquito Control District staff from May 1998 to August 2010. Larvae and pupae were collected via use of dippers, pipettes, or aquarium nets. Adults were collected in various kinds of traps, such as CDC light traps, ABC light traps (unbaited or baited with carbon dioxide), BG Sentinel ${ }^{\circledR}$ traps, and Mosquito Magnet ${ }^{\circledR}$ traps. All specimens were identified by District staff, except for a few that were sent to a taxonomist for identification or verification. Voucher specimens are deposited in the Florida State Collection of Arthropods, the Yale University Peabody Museum of Natural History, and the collection maintained by the Florida Keys Mosquito Control District. Collections on Federal and State lands were made after issuance of permits by the United States Fish and Wildlife Service or the Florida Department of Environmental Protection.

\section{RESULTS AND DisCuSSION}

Forty-eight species or species groups of mosquitoes have been reported from the Florida Keys (Table 1). One difficulty in tracing the development of the faunal list of mosquitoes from the Florida Keys is that there were numerous changes in nomenclature during the early Twentieth Century and there is often an abundance of synonyms to unravel. This review of the mosquito fauna of the Florida Keys will present a historical treatment of the development of knowledge of the mosquito fauna of the Florida Keys. Generic and subgeneric abbreviations follow Reinert (1975).

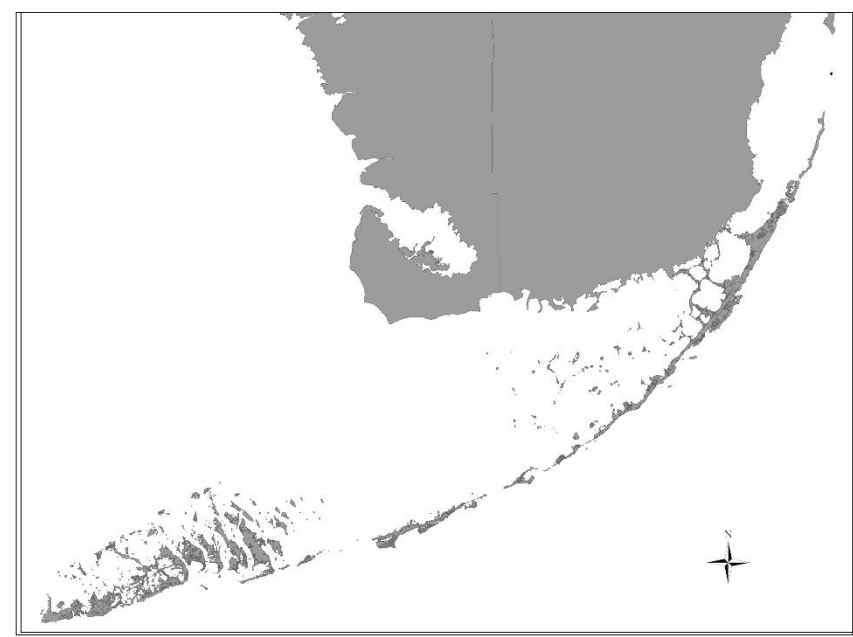

FIGURE 1. The southern portion of the Florida peninsula and the Florida Keys. 
TABLE 1. The southern portion of the Florida peninsula and the Florida Keys.

\begin{tabular}{lll}
\hline & TAXON & LOCALITY \\
\hline ANOPHELINAE &
\end{tabular}

Annette Key, Bahia Honda Key, Big Coppitt Key, Big Pine Key, Big Torch Key, Boca Chica Key, Cross Key, Cudjoe Key, Elliott Key, Geiger Key, Grassy Key, Howe Key, Indian Key,

Anopheles (Anopheles) atropos Dyar and Knab

\author{
An. (Ano.) bradleyi King \\ An. (Ano.) crucians Wiedemann
}

An. (Ano.) crucians complex (females)

An. (Ano.) grabhamii Theobald

An. (Ano.) quadrimaculatus complex

An. (Ano.) walkeri Theobald

An. (Nyssorhynchus) albimanus Wiedemann

\section{CULICINAE}

AEdinI

Aedes (Ochlereotatus) atlanticus Dyar and Knab

Ae. (Och.) condolescens Dyar and Knab

Ae. (Och.) infirmatus Dyar and Knab

Ae. (Och.) mitchellae (Dyar)

Ae. (Och.) scapularis (Rondani)

Ae. (Och.) sollicitans (Walker)

Ae. (Och.) taeniorhynchus (Wiedemann)

Ae. (Och.) thelcter Dyar
Key Largo, Key West, Lignumvitae Key, Little Pine Key, Little Knockemdown Key, Long Key, Long Point Key, Lower Matecumbe Key, Middle Torch Key, No Name Key, Plantation Key, Pumpkin Keys, Raccoon Key, Ramrod Key, Stock Island, Sugarloaf Key, Summerland Key, Sunrise Cay, “Torch Key”, Upper Matecumbe Key, Vaca Key, Water Key, Water Keys, Windley Key

Key Largo, Lower Matecumbe Key

Big Pine Key, Indian Key, Lower Matecumbe Key, Ramrod Key

Annette Key, Bahia Honda Key, Big Coppitt Key, Big Pine Key, Big Torch Key, Boca Chica Key, Cross Key, Cudjoe Key, Geiger Key, Grassy Key, Key Largo, Key West, Lignumvitae Key, Little Knockemdown Key, Little Pine Key, Long Key, Middle Torch Key, No Name Key, Plantation Key, Raccoon Key, Rodriguez Key, Stock Island, Sugarloaf Key, Summerland Key, Sunrise Cay, Upper Matecumbe, Vaca Key, Water Keys, Windley Key

Big Pine Key, Big Torch Key, Key West, Middle Torch Key, No Name Key, Sugarloaf Key

Big Pine Key, Big Torch Key, Key Largo, Key West, Plantation Key, Sugarloaf Key

Key Largo

Big Pine Key, Crawl Key, Grassy Key, Key Largo, Key West, Long Key, Lower Matecumbe Key, No Name Key, Stock Island, Upper Matecumbe Key, Vaca Key

Annette Key, Big Pine Key, Big Torch Key, Cudjoe Key, Grassy Key, Key Largo, Lignumvitae Key, Little Knockemdown Key, Long Key, No Name Key, Plantation Key, Stock Island, Windley Key

Annette Key, Big Coppitt Key, Big Pine Key, Big Torch Key, Boca Chica Key, Boot Key, Cross Key, Cudjoe Key, Geiger Key, Grassy Key, Howe Key, Key Largo, Key West, Lignumvitae Key, Little Knockemdown Key, Little Pine Key, Long Key, Middle Torch Key, No Name Key, Plantation Key, Raccoon Key, Ramrod Key, Rodriguez Key, Stock Island, Sugarloaf Key, Summerland Key, Sunrise Cay, Upper Matecumbe Key, Vaca Key, Water Keys, Windley Key

Big Pine Key, Big Torch Key, Cudjoe Key, Cross Key, Geiger Key, Grassy Key, Key Largo, Key West, Little Knockemdown Key, Long Key, No Name Key, Plantation Key, Stock Island, Sugarloaf Key, Upper Matecumbe Key, Vaca Key, Windley Key

Big Torch Key

Vaca Key

Annette Key, Big Pine Key, Big Torch Key, Boca Chica Key, Cross Key, Cudjoe Key, Grassy Key, Horseshoe Key, Howe Key, Johnson Key, Key Largo, Key West, Lignumvitae Key, Little Knockemdown Key, Little Pine Key, Long Key, Long Point Key, Middle Torch Key, No Name Key, Plantation Key, Raccoon Key, Ramrod Key, Stock Island, Sugarloaf Key, Summerland Key, Vaca Key, Water Key, Water Keys

Annette Key, Bahia Honda Key, Bamboo Key, Big Coppitt Key, Big Munson Key, Big Pine Key, Big Torch Key, Boca Chica Key, Boot Key, “Crawl Keys”, Cross Key, Cudjoe Key, Duck Key, Fat Deer Key, Geiger Key, Grassy Key, Horseshoe Key, Howe Key, Indian Key, Johnson Key, Key Largo, Key West, Knights Key, Lignumvitae Key, Little Knockemdown Key, Little Pine Key, Loggerhead Key, Long Key, Long Point Key, Lower Matecumbe Key, Middle Torch Key, No Name Key, Plantation Key, Raccoon Key, Ramrod Key, Stock Island, Sugarloaf Key, Summerland Key, Toptree Hammmock Key, “Torch Key”, Upper Matecumbe Key, Vaca Key, Water Key, Water Keys, Windley Key

Big Coppitt Key, Boca Chica Key, “Crawl Key No. 1”, Key Largo, Key West, Long Key, Vaca Key 
Annette Key, Big Coppitt Key, Big Pine Key, Big Torch Key, Boca Chica Key, Boot Key,

Ae. (Och.) tortilis (Theobald) "Crawl Keys", Cross Key, Cudjoe Key, Geiger Key, Grassy Key, Key Largo, Key West, Lignumvitae Key, Little Pine Key, Long Key, Lower Matecumbe Key, Middle Torch Key, No Name Key, Plantation Key, Ramrod Key, Stock Island, Sugarloaf Key, Summerland Key, Upper Matecumbe Key, Vaca Key, Water Keys, Windley Key

Ae. (Protomacleaya) triseriatus (Say)

Ae. (Stegomyia) aegypti Linnaeus

Ae. (Stg.) albopictus (Skuse)

Psorophora (Psorophora) ciliata (F.)

Ps. (Pso.) howardii Coquillett

Ps. (Grabhamia) columbiae (Dyar and Knab)

Ps. (Gra.) pygmaea (Theobald)

Ps.(Janthinosoma) ferox (Von Humboldt)

Ps. (Jan.) johnstonii (Grabham)

\section{Culisetini}

Culiseta (Climacura) melanura (Coquillett)

Cs. (Culiseta) inornata (Williston)

\section{Culicini}

Culex (Culex) bahamensis Dyar and Knab

Cx. (Cux.) declarator Dyar and Knab

Cx. (Cux.) nigripalpus Theobald
Annette Key, Big Pine Key, Big Torch Key, Boca Chica Key, Boot Key, Cudjoe Key, Cross Key, Indian Key, Key Largo, Lignumvitae Key, Little Knockemdown Key, Little Pine Key, Long Key, Plantation Key, Rodriguez Key, Sugarloaf Key, Summerland Key, Sunrise Cay, Upper Matecumbe Key, Water Keys, Windley Key

Annette Key, Bahia Honda Key, Big Coppitt Key, Big Pine Key, Big Torch Key, Crawl Key, Cross Key, Cudjoe Key, Duck Key, Fat Deer Key, Geiger Key, Grassy Key, Key Largo, Key West, Lignumvitae Key, Little Pine Key, Little Torch Key, Long Key, Lower Matecumbe Key, Middle Torch Key, No Name Key, Plantation Key, Ramrod Key, Rodriguez Key, Saddlebunch Keys, Shelter Key, Stock Island, Sugarloaf Key, Summerland Key, Sunrise Cay, Upper Matecumbe Key, Vaca Key, Windley Key

Big Pine Key, Key Largo, Key West, Stock Island, Upper Matecumbe Key

Annette Key, Big Pine Key, Big Torch Key, Cudjoe Key, Grassy Key, Key Largo, Key West, Little Knockemdown Key, Little Pine Key, Middle Torch Key, No Name Key, Raccoon Key, Stock Island, Sugarloaf Key, Summerland Key, Water Key, Water Keys

Stock Island

Annette Key, Big Pine Key, Big Torch Key, Boca Chica Key, Cudjoe Key, Geiger Key, Grassy Key, Key Largo, Key West, Little Pine Key, Long Key, Middle Torch Key, No Name Key, Ramrod Key, Stock Island, Sugarloaf Key

Annette Key, Big Coppitt Key, Pig Pine Key, Boca Chica Key, Cudjoe Key, Geiger Key, Key West, Middle Torch Key, Ramrod Key, Sugarloaf Key, Summerland Key

Annette Key, Big Pine Key, Big Torch Key, Boca Chica Key, Cudjoe Key, Key Largo. Little Pine Key, Middle Torch Key, Sugarloaf Key

Annette Key, Big Coppitt Key, Big Pine Key, Big Torch Key, Boca Chica Key, Cudjoe Key, Geiger Key, Key Largo, Key West, Lignumvitae Key, Little Knockemdown Key, Little Pine Key, Long Key, Lower Matecumbe Key, Middle Torch Key, No Name Key, Plantation Key, Raccoon Key, Ramrod Key, Sugarloaf Key, Summerland Key, Vaca Key, Water Keys, Windley Key

No Name Key

Big Pine Key, Big Torch Key, Boot Key, Geiger Key, Grassy Key, Key Largo, Little Pine Key, Middle Torch Key, No Name Key, Stock Island, Sugarloaf Key, Water Keys

Annette Key, Bahia Honda Key, Big Coppitt Key, Big Pine Key, Big Torch Key, Boca Chica Key, Cudjoe Key, Elliott Key, Fat Deer Key, Geiger Key, Johnson Key, Key Largo, Key West, Knights Key, Lignumvitae Key, Little Knockemdown Key, Little Pine Key, Long Key, Long Point Key, Lower Matecumbe Key, Middle Torch Key, No Name Key, Plantation Key, Pumpkin Keys, Raccoon Key, Ramrod Key, Stock Island, Sugarloaf Key, Summerland Key, Upper Matecumbe Key, Vaca Key, Water Key, Water Keys, Windley Key

Big Coppitt Key, Big Pine Key, Big Torch Key, Cross Key, Cudjoe Key, Geiger Key, Key Largo, Key West, Little Knockemdown Key, Little Pine Key, Long Key, Middle Torch Key, No Name Key, Ramrod Key, Stock Island, Sugarloaf Key, Summerland Key, Sunrise Cay, Upper Matecumbe Key, Vaca Key

Annette Key, Big Coppitt Key, Big Pine Key, Big Torch Key, Boca Chica Key, Boot Key, Cross Key, Cudjoe Key, Geiger Key, Grassy Key, Key Largo, Key West, Lignumvitae Key, Little Knockemdown Key, Little Pine Key, Long Key, Long Point Key, Middle Torch Key, No Name Key, Plantation Key, Raccoon Key, Ramrod Key, Stock Island, Sugarloaf Key, Summerland Key, Upper Matecumbe Key, Vaca Key, Water Keys, Windley Key 


\begin{tabular}{|c|c|}
\hline TAXON & LOCALITY \\
\hline Cx. (Cux.) quinquefasciatus Say & $\begin{array}{l}\text { Annette Key, Big Coppitt Key, Big Pine Key, Big Torch Key, Boca Chica Key, Boot Key, Cross } \\
\text { Key, Cudjoe Key, Duck Key, Fat Deer Key, Geiger Key, Grassy Key, Key Largo, Key West, } \\
\text { Lignumvitae Key, Little Pine Key, Long Key, Lower Matecumbe Key, Middle Torch Key, } \\
\text { No Name Key, Plantation Key, Ramrod Key, Stock Island, Sugarloaf Key, Summerland Key, } \\
\text { Upper Matecumbe Key, Vaca Key, Windley Key }\end{array}$ \\
\hline Cx. (Cux.) salinarius Coquillett & Big Pine Key, Cudjoe Key, Geiger Key, Grassy Key, Key Largo, Vaca Key, Stock Island \\
\hline Cx. (Melanoconion) atratus Theobald & $\begin{array}{l}\text { Annette Key, Big Pine Key, Big Torch Key, Boca Chica Key, “Crawl Keys”, Cudjoe Key, Elliott } \\
\text { Key, Geiger Key, Grassy Key, Key Largo, Key West, Lignumvitae Key, Little Knockemdown } \\
\text { Key, Little Pine Key, Long Key, Lower Matecumbe Key, Middle Torch Key, No Name Key, } \\
\text { Plantation Key, Ramrod Key, Saddlebunch Keys, Stock Island, Sugarloaf Key, Summerland } \\
\text { Key, “Torch Key”, Vaca Key, Water Keys, Windley Key }\end{array}$ \\
\hline Cx. (Mel.) cedecei Stone and Hair & $\begin{array}{l}\text { Big Pine Key, Big Torch Key, Key Largo, Key West, Little Knockemdown Key, Stock Island, } \\
\text { Sugarloaf Key }\end{array}$ \\
\hline CX. (Mel.) erraticus Dyar and Knab & $\begin{array}{l}\text { Big Pine Key, Big Torch Key, Cudjoe Key, Cross Key, Geiger Key, Grassy Key, Key Largo, } \\
\text { Key West, Long Key, No Name Key, Stock Island, Sugarloaf Key, Upper Matecumbe Key }\end{array}$ \\
\hline Cx. (Mel.) iolambdis Dyar & $\begin{array}{l}\text { Annette Key, Big Pine Key, Cudjoe Key, Geiger Key, Key Largo, Key West, Long Key, No } \\
\text { Name Key, Plantation Key, Stock Island, Upper Matecumbe Key, Vaca Key, Windley Key }\end{array}$ \\
\hline Cx. (Mel.) mulrennani Basham & Big Pine Key, Cudjoe Key, Key Largo, Long Key, Ramrod Key \\
\hline Cx. (Mel.) peccator Dyar and Knab & $\begin{array}{l}\text { Big Pine Key, Big Torch Key, Boca Chica Key, Cudjoe Key, Geiger Key, Key Largo, Key West, } \\
\text { Little Knockemdown Key, Little Pine Key, Long Key, Middle Torch Key, No Name Key, } \\
\text { Plantation Key, Stock Island, Sugarloaf Key, Summerland Key, Upper Matecumbe Key, } \\
\text { Water Keys }\end{array}$ \\
\hline CX. (Mel.) pilosus Dyar and Knab & $\begin{array}{l}\text { Big Pine Key, Cudjoe Key, Geiger Key, Key Largo, Little Knockemdown Key, Little Pine } \\
\text { Key, Stock Island, “Torch Key’, Vaca Key }\end{array}$ \\
\hline Deinocerites cancer Theobald & $\begin{array}{l}\text { Annette Key, Bahia Honda Key, Big Coppitt Key, Big Pine Key, Big Torch Key, Boca Chica } \\
\text { Key, Boot Key, Cross Key, Cudjoe Key, Geiger Key, Key Largo, Lignumvitae Key, Little } \\
\text { Knockemdown Key, Little Pine Key, Long Key, Middle Torch Key, No Name Key, Plantation } \\
\text { Key, Raccoon Key, Ramrod Key, Rodriguez Key, Stock Island, Sugarloaf Key, Summerland } \\
\text { Key, Sunrise Cay, Vaca Key, Water Keys, Windley Key }\end{array}$ \\
\hline \multicolumn{2}{|l|}{ MANSONIINI } \\
\hline Coquillettidia (Coquillettidia) perturbans (Walker) & Annette Key, Key Largo, Little Knockemdown Key, Long Key \\
\hline Mansonia (Mansonia) dyari Belkin, Heinemann, and Page & Big Pine Key, Grassy Key \\
\hline Ma. (Man.) titillans (Walker) & Long Key, Vaca Key \\
\hline \multicolumn{2}{|l|}{ SABETHINI } \\
\hline Wyeomyia (Wyeomyia) mitchellii (Theobald) & Big Pine Key, Cudjoe Key \\
\hline Wy. (Wyo.) vanduzeei Dyar and Knab & Big Pine Key, Big Torch Key, Key Largo, Little Knockemdown Key, Ramrod Key \\
\hline \multicolumn{2}{|l|}{ URANOTAENIINI } \\
\hline Uranotaenia (Uranotaenia) lowii Theobald & $\begin{array}{l}\text { Annette Key, Big Pine Key, Big Torch Key, Cross Key, Cudjoe Key, Grassy Key, Key Largo, } \\
\text { Little Knockemdown Key, Little Pine Key, Long Key, Lower Matecumbe Key, Middle Torch } \\
\text { Key, No Name Key, Plantation Key, Rodriguez Key, Stock Island, Sugarloaf Key, Sunrise } \\
\text { Cay, Upper Matecumbe Key, Vaca Key, Windley Key }\end{array}$ \\
\hline Ur. (Ura.) sapphirina (Osten Sacken) & Stock Island \\
\hline
\end{tabular}

\section{Early Twentieth Century}

During the early years of the Twentieth Century, the 1900 s to the 1930 s, very little work was done on the mosquitoes of the Florida Keys. A few species were reported but there was no sustained effort to record the fauna. The first published records of mosquitoes from the Florida Keys were in Coquillett's description of Culex nanus (Coquillett 1903). Coquillett described his new species based on 10 specimens, four collected in August 1901 in Key West by August Busck, and six others collected 1 to 3 April 1903 by E.A. Schwarz. Culex nanus is now regarded as a synonym of Psorophora pygmaea (Theobald) (Dyar and Knab 1906). A year later, in 1904, Gardner (1904) reported the presence of Anopheles albimanus Wiedemann in Key West (as An. argyritarsis albipes Theobald, see Rozeboom and Gabaldón (1941) for discussion of synonymy). Dyar and Knab (1906) described Anopheles atropos from the "Florida Keys"; they did not specify a locality. Johnson (1913), in his treatment of the Diptera of Florida, listed eight mosquito species in the Florida Keys, viz., Anopheles albimanus, An. atropos, Psorophora ciliata (as Psorophora ciliatus [sic]), Psorophora pygmaea 
(as Janthinosoma pygmaea), Aedes aegypti (as Stegomyia calopus, see Dyar 1920), Aedes taeniorhynchus (as Aedes niger), Culex quinquefasciatus, and Culex bahamensis (as Culex corniger). The name "Psorophora ciliatus" is most likely a typographic error; nowhere else has this species been given that epithet. Since its description by Fabricius, it has always been "ciliata".

In 1915, Howard, Dyar, and Knab mentioned generally that Deinocerites cancer and Wyeomyia mitchellii (Theobald) (as Wy. antoinetta Dyar and Knab) were found in "Southern Florida"; they also reported $C x$. bahamensis from Knights Key (as Cx. corniger) and Cx. quinquefasciatus Say from Key West. In 1917, Howard, Dyar, and Knab included records of Ps. ciliata from Key West collected by Busck in August of 1901; the above mentioned records of Ps. pygmaea, Ae. taeniorhynchus from Knights Key and Key West (as Ae. niger); Ae. aegypti from Key West (as Ae. calopus), An. albimanus from Key West; An. atropos from "Florida Keys". Dyar (1922) included earlier records of Coquillett (1903), Johnson (1913), and Howard et al. (1915; 1917), and reported a new record of Ae. sollicitans from Ramrod Key. Two years later Moznette (1924) reported the presence of Ae. taeniorhynchus on Bamboo Key. Toward the end of the 1930s, previously reported records of mosquitoes from the Florida Keys were included in a review of the distribution of An. albimanus (King 1937) and a handbook for identification of mosquitoes of the southeastern United States (King et al. 1939). At the end of the decade, Fisk (1939) reported An. atropos and Cx. bahamensis from the island of Key West. King and Bradley (1941) reviewed the distribution of Anopheles species in the United States, citing earlier records of An. albimanus and An. atropos in the Florida Keys.

\section{Second World War}

The outbreak of the Second World War stimulated research on mosquitoes throughout the world. King et al. (1942) updated their handbook of mosquitoes of the southeastern United States; in this revision they included new records of $C x$. bahamensis from Elliott Key. A number of new records were reported from the Florida Keys during this period. Several species were described from material collected in the Florida Keys, as well. Roth and Young (1944) reported a new species record, CX. atratus, from the Florida Keys. Wirth (1945) reported Ae. taeniorhynchus from Key Largo. In this same paper he also reported $C x$. (Melanoconion) elevator Dyar and Knab from Key Largo. Pratt and Seabrook (1952), however, determined that these specimens actually were $C x$. (Mel.) iolambdis Dyar. Staebler and Buren (1946) recorded a new national record, Ae. tortilis, from Key West. Buren (1946) also confirmed the establishment of Ps. pygmaea in Florida. Buren (1947) also described a new species, Ae. keyensis, from Key West. Thurman and coauthors (1949) later synonymized Ae. keyensis with Ae. thelcter Dyar, and reported records from Long Key, Key Largo, Key West, and Vaca Key.

The publication of an annotated list of Florida Keys mosquitoes by Pritchard et al. (1947) added many new records to the fauna of the Florida Keys. In total, 28 species were recorded, including Ae. euplocamus Dyar and Knab and Ps. confinnis (Lynch Arribalzaga). Arnell (1976), however, stated that Ae. euplocamus was known only from Mexico, Costa Rica, El Salvador, Panama, Colombia, and Venezuela, and that the specimens from Vaca Key misidentified as Ae. euplocamus by Pritchard et al. (1947) were actually Ae. scapularis (Rondani). Furthermore, Bickley (1984) reported that Ps. confinnis did not occur in the southeastern United States, and that the proper identity of this Psorophora species was Ps. columbiae Dyar and Knab.

Anopheles quadrimaculatus Say had not been reported from the Florida Keys during any of the prior mosquito surveys, although it had been collected from the near adjacent mainland (Thurman 1948). In 1948, Basham and Haeger (1948) reported the collection of small numbers of An. quadrimaculatus from Big Pine Key, Key Largo, and Plantation Key. Reinert et al. (1997) eventually determined that the nominal species An. quadrimaculatus was a complex of five morphologically similar species. They did not assign the records of Basham and Haeger to any of the five species described in their paper.

Pritchard et al. (1947) reported collecting an undescribed Culex species during their survey of the mosquitoes of the Florida Keys. Basham (1948) described a new species of Culex (Melanoconion), Cx. (Mel.) mulrennani, from material collected on Big Pine, Cudjoe, and Ramrod Keys; this was the undescribed species reported previously by Pritchard et al (1947).

\section{Post World War Two}

The decades of the 1950s and 1960s saw very little work on the mosquitoes of the Florida Keys. Branch et al. (1958) collected Mansonia titillans (Walker) from Vaca Key, and An. albimanus from several islands. These authors also reported Ae. (Aedemorphus) vexans (Meigen) and Ma. indubitans (Dyar and Shannon) from Monroe County. No island was specified, and these records most likely refer to the mainland portion of Monroe County. In their description of Ma. dyari, Belkin et al. (1970) stated that all records of Ma. indubitans from Florida and elsewhere in the southeastern United States were likely Ma. dyari. Moreover, Branch et al. (1958) reported Cx. opisthopus from the mainland of Monroe County. Stone and Hair (1968) described Cx. cedecei from Florida and stated that all records of $C x$. opisthopus in the United States correctly were Cx. cedecei. In 1960, King et al. (1960) again updated their manual of mosquitoes of the southeastern United States.

\section{Late Twentieth Century and Twenty-First Century}

Beginning in the late 1990s and continuing until the present, the Florida Keys Mosquito Control District has surveyed the Florida Keys and has reported numerous new distribution records within the island chain. Three species new to the fauna of the United States were recognized based entirely or in part on specimens collected in the Florida Keys. Other species that had not been collected for years were recorded once again from the Florida Keys. Hribar (1999) collected An. albimanus from Long Key and No Name Key. Hribar (2001) made the first report of CX. peccator Dyar and Knab from Monroe County, on Big Pine Key. In that same paper Ps. johnstonii was reported from Summerland Key for the first time. Hribar and Vlach (2001) reported several mosquito species from state 
parks in the Florida Keys, including records from Bahia Honda Key. Hribar et al. (2001) presented larval collection records from several islands in the area of Key West. Hribar (2002) analyzed collection records from a number of islands within the Florida Keys, and reported Culiseta melanura Coquillett from No Name Key. Darsie et al. (2002) reported a new addition to the fauna of the United States, An. grabhamii Theobald, from Big Pine Key. Later, Hribar (2005) reported An. grabhamii from No Name Key. Darsie (2003) reported the first collections of Ae. condolescens Dyar and Knab from Annette Key, Big Pine Key, and Howe Key. Later Hribar et al. (2005) reported Ae. condolescens from 22 different islands within the Florida Keys. Darsie and Shroyer (2004) reported Cx. declarator Dyar and Knab from Big Pine Key, Key Largo, and Long Key.

ACKNOWLEDGMENTS: The authors thank the numerous inspectors and technicians employed by the Florida Keys Mosquito Control District who throughout the years have collected specimens. We also thank Kristen Bird for preparing the figure. Dr. R.F. Darsie, Jr. identified or verified some of the specimens reported herein.

\section{Literature Cited}

Arnell, J.H. 1976. Mosquito studies (Diptera, Culicidae). XXXIII. A revision of the scapularis group of Aedes (Ochlerotatus). Contributions of the American Entomological Institute 13(3): 1-144.

Basham, E.H. 1948. Culex (Melanoconion) mulrennani, a new species from Florida. Annals of the Entomological Society of America 41(1): 1-7.

Basham, E.H. and J.S. Haeger. 1948. Records of Anopheles quadrimaculatus Say for the Florida Keys. Mosquito News 8(1): 72.

Belkin, J.N., S.J. Heinemann and W.A. Page. 1970. The Culicidae of Jamaica (Mosquito Studies, XXI). Contributions of the American Entomological Institute 6(1): 1-458.

Bickley, W.E. 1984. Notes on the Psorophora confinnis complex. Mosquito Systematics 16(2): 162-167.

Branch, N., L. Logan, E.C. Beck and J.A. Mulrennan. 1958. New distributional records for Florida mosquitoes. Florida Entomologist 41(4): 155-163.

Buren, W.F. 1946. Psorophora pygmaea (Theobald), an exotic mosquito now established in Florida. Mosquito News 6(4): 185.

Buren, W.F. 1947. A new Aedes from the Florida Keys. Proceedings of the Entomological Society of Washington 61(8): 228-229.

Coquillett, D.W. 1903. Four new species of Culex. Canadian Entomologist 35(9): 255-257.

Corbett, D.R., J. Chanton, W. Burnett, K. Dillon, C. Rutkowski and J.W. Fourqurean. 1999. Patterns of groundwater discharge into Florida Bay. Limnology and Oceanography 44(4): 1045-1055.

Darsie, R.F., Jr. 2003. First report of Ochlerotatus condolescens (Dyar and Knab) (Diptera: Culicidae) in the United States. Proceedings of the Entomological Society of Washington 105(4): 1067-1068.

Darsie, R.F., Jr. and C.D. Morris. 2000. Keys to the adult females and fourth instar larvae of the mosquitoes of Florida. Technical Bulletin of the Florida Mosquito Control Association Volume 1 (revised). 159 p.

Darsie, R.F., Jr. and D.A. Shroyer. 2004. Culex (Culex) declarator, a mosquito species new to Florida. Journal of the American Mosquito Control Association 20(3): 224-227.

Darsie, R.F., Jr., J.J. Vlach and E.M. Fussell. 2002. New addition to the mosquito fauna of United States, Anopheles grabhamii (Diptera: Culicidae). Journal of Medical Entomology 39(3): 430- 431.

DeMay, D.J. and L.J. Hribar. 2005. Species composition, seasonal distribution, and relative abundance of mosquitoes (Diptera: Culicidae) on Lignumvitae Key in the Florida Keys, USA. Trends in Entomology 4: 71-74.

DeMay, D.J. and L.J. Hribar. 2008. Mosquito fauna of Key Largo, Florida. Journal of the American Mosquito Control Association 24(4): 471-477.

DeMay, D.J. and L.J. Hribar. 2009. Mosquito (Diptera: Culicidae) collection records from Boot Key, Florida. Florida Scientist 72(3): 240-241.

Dyar, H.G. 1920. The earliest name of the yellow fever mosquito (Diptera, Culicidae). Insecutor Inscitiae Menstruus 8(10-12): 204.

Dyar, H.G. 1922. The mosquitoes of the United States. Proceedings of the United States National Museum 62: 1-119.

Dyar, H.G. and F. Knab. 1906. Notes on some American mosquitoes with descriptions of new species. Proceedings of the Biological Society of Washington 19(6): 159-172.
DeMay and Hribar (2005) recorded fifteen species of mosquitoes from Lignumvitae Key. Of those, the most abundantwere Ae.taeniorhynchus, De.cancer, Ps.johnstonii, and An. atropos. Hribar (2007) described the collection of Cs. inornata from No Name Key, Big Pine Key, and Grassy Key after strong winds from the north. DeMay and Hribar (2008) collected 28 species of mosquitoes from Key Largo, including the first records of $C x$. cedecei, $C x$. peccator, $C x$. salinarius, and Cs. inornata from this island. Later, DeMay and Hribar (2009) provided the only published records of mosquitoes on Boot Key; ten species were collected, including Cs. inornata and Ae. triseriatus Say. Finally, Leal and Hribar (2010) reported the collection of 30 mosquito species from wilderness islands within the National Key Deer Refuge and the Great White Heron National Wildlife Refuge.

Fisk, F.W. 1939. New mosquito records from Key West. Journal of Economic Entomology 32(3): 469.

Gardner, C.H. 1904. Anopheles mosquitoes found at Key West, Florida. Public Health Reports 195(34): 1651.

Hoffmeister, J.E. and H.G. Multer. 1968. Geology and origin of the Florida Keys. GSA Bulletin 9(11): 1487-1502.

Howard. L.O., H.G. Dyar and F. Knab. 1915. The Mosquitoes of North and Central America and the West Indies. Systematic Description, part I. Carnegie Institute of Washington Publication 159(3): 1-523.

Howard. L.O., H.G. Dyar and F. Knab. 1917. The Mosquitoes of North and Central America and the West Indies. Systematic Description, part II. Carnegie Institute of Washington Publication 159(4): 525-1064.

Hribar, L.J. 1999. Continued presence of Anopheles albimanus (Diptera: Culicidae) in Monroe County, Florida. Entomological News 110(5): 317-319.

Hribar, L.J. 2001. Uncommonly collected mosquitoes from the Florida Keys. Entomological News 112(2): 123.

Hribar, L.J. 2002. Mosquito (Diptera: Culicidae) collections in the Florida Keys, Monroe County, Florida, USA. Studia Dipterologica 9(2): 679691.

Hribar, L.J. 2005. New locality record for Anopheles grabhamii (Diptera: Culicidae) from the Florida Keys. Florida Scientist 68(2): 8-10.

Hribar, L.J. 2007. New and old mosquito records for extreme southern Florida. Insecta Mundi 5: 1-3.

Hribar, L.J. and J.J. Vlach. 2001. Mosquito (Diptera: Culicidae) and biting midge (Diptera: Ceratopogonidae) collections in Florida Keys state parks. Florida Scientist 64(3): 219-223.

Hribar, L.J., J. M. Smith, J.J. Vlach and T.N. Verna. 2001. Survey of container- breeding mosquitoes from the Florida Keys, Monroe County, Florida. Journal of the American Mosquito Control Association 17(4): 245-248.

Hribar, L.J., D.J. DeMay, M.J. Hemmen and A.L. Leal. 2005. Observations on the distribution and seasonality of Ochlerotatus condolescens (Dyar \& Knab) in the Florida Keys, USA (Diptera: Culicidae). Studia Dipterologica 12(1): 361-362.

Johnson, C.W. 1913. Insects of Florida. III. Diptera. Bulletin of the American Museum of Natural History 32: 37-90.

King, W.V. 1937. On the distribution of Anopheles albimanus and its occurrence in the United States. Southern Medical Journal 30(9): 943-946.

King, W.V. and G.H. Bradley. 1941. Distribution of the Nearctic species of Anopheles. American Association for the Advancement of Science Publication 15: 71-78.

King, W.V., G.H. Bradley, and T. E. McNeel. 1939. The mosquitoes of the southeastern states. USDA Miscellaneous Publication 36. 1-87.

King, W.V., G.H. Bradley, and T. E. McNeel. 1942. The mosquitoes of the southeastern states, revised. USDA Miscellaneous Publication 336. 1-95.

King, W.V., G.H. Bradley, C.N. Smith, and W.C. McDuffie. 1960. A handbook of the mosquitoes of the southeastern United States. USDA Agriculture Handbook 173. 188 p.

Leal, A.L. and L.J. Hribar. 2010. Mosquito fauna of wilderness islands within the National Key Deer Refuge and the Great White Heron National Wildlife Refuge, Monroe County, Florida. Journal of the American Mosquito Control Association 26(2): 141-147.

Pratt, H.D. and E.L. Seabrook. 1952. The occurrence of Culex iolambdis Dyar in Florida and Puerto Rico, with a description of the larva. Proceedings of the Entomological Society of Washington 54(1): 27-32. 
Pritchard, A.E., E.L. Seabrook and J.A. Mulrennan. 1947. The mosquitoes of the Florida Keys. Florida Entomologist 30(1-2): 8-15.

Reinert, J.F. 1975. Mosquito generic and subgeneric abbreviations (Diptera: Culicidae). Mosquito Systematics 7(2): 105-110.

Reinert, J.F., P.E. Kaiser and J.A. Seawright. 1997. Analysis of the Anopheles (Anopheles) quadrimaculatus complex of sibling species (Diptera: Culicidae) using morphological, cytological, molecular, genetic, biochemical, and ecological techniques in an ecological approach. Journal of the American Mosquito Control Association 13(Supplement): 1-102.

Ross, M.S., J.J. O’Brien and L.J. Flynn. 1992. Ecological site classification of Florida Keys terrestrial habitats. Biotropica 24(4): 488-502.

Roth, L.M. and F.N. Young. 1944. Culex (Melanoconion) atratus Theobald in Florida: a new North American continental record, with notes on the other Melanoconions of the southeastern United States. Annals of the Entomological Society of America 37(1): 84-88.

Rozeboom, L.E. and A. Gabaldón. 1941. A summary of the "tarsimaculatus" complex of Anopheles (Diptera; Culicidae). American Journal of Hygiene 33(3): 88-100.

Snyder, J.R., A. Herndon and W.B. Robertson, Jr. 1990. South Florida rockland; p. 230-277 In R.L. Myers and J.J. Ewel (ed.). Ecosystems of Florida. University of Central Florida Press.
Staebler, A.E. and W.F. Buren. 1946. Aedes tortilis (Theobald), a mosquito new to the United States. Entomological News 57(6): 157.

Stern, W.L. and G.K. Brizicky. 1957. The woods and flora of the Florida Keys. Introduction. Tropical Woods 107: 36-65.

Stone, A. and J.A. Hair. 1968. A new Culex (Melanoconion) form Florida (Diptera, Culicidae). Mosquito News 28(1): 39-41.

Thurman, D.C., Jr. 1948. A far south record of Anopheles quadrimaculatus Say. Mosquito News 8(1): 19.

Thurman, E.B., J.S. Haeger and J.A Mulrennan. 1949. The occurrence of Aedes (Ochlerotatus) thelcter Dyar in the Florida Keys. Mosquito News 9(4): 171-172.

Wirth, W.W. 1945. The occurrence of Culex (Melanoconion) elevator Dyar and Knab in Florida, with keys to the Melanoconions of the United States. Proceedings of the Entomological Society of Washington 47(7): 199-210.

RECEIVED: September 2010

LAST REVISED: April 2011

ACCEPTED: June 2011

PUBLISHED ONLINE: July 2011

EDITORIAL RESPONSIBILITY: Cristiano Lopes-Andrade 


\section{Mosquitoes (Insecta: Diptera: Culicidae) of the Florida Keys, Florida, United States of America}

Lawrence J. Hribar ${ }^{1 *}$, Andrea L. Leal ${ }^{2}$, David J. DeMay ${ }^{1}$ and Adriane N. Tambasco ${ }^{3}$

1 Florida Keys Mosquito Control District, 503 107th Street, Marathon, FL 33050, USA.

2 Florida Keys Mosquito Control District, 5224 College Road, Key West, FL 33040, USA

3 Florida Keys Mosquito Control District, 100701 Overseas Highway, Key Largo, FL 33037, USA.

* Corresponding author. Email: Ihribar@keysmosquito.org

\section{ERRATUM}

PAgE 459: Heading of TABLE 1 should be: Culicidae known to occur in the Florida Keys.

PAGE 459: Within TABLE 1, Aedes (Ochlereotatus) atlanticus, subgenus should be "Ochlerotatus".
We regret these errors.

August 2011. 